\title{
Growth, Nutrient Digestibility and Carcass Indices of Rabbits fed Varying Levels of Sugarcane Rind Meal
}

Adeosun, T. A. and *Iyeghe-Erakpotobor, G. T.

Department of Agricultural Science Education,

Federal College of Education (Tech.), Bichi, Nigeria

* National Animal Production Research Institute,Ahmadu Bello University, Zaria, Nigeria.

Corresponding author: gtierak@yahoo.com,

g.t.iyeghe-erakpotobor@napri-ng.org

\section{Abstract}

The potential of sugarcane peels as a substitute for maize offal in rabbit diets and its effect on growth, mutrient digestibility, and carcass characteristics were studied. Twenty five growing rabbits of mixed breeds and average body weight of $894 \pm 26.14 \mathrm{~g}$ were used in a 7-week feeding trial. Five experimental diets were formulated in which sugarcane rind (SCR) was included at 0,10,20, 30 and $40 \%$ level to replace maize offal (weight for weight). The rabbits were balanced for weight and allotted to the treatments ( $n=5$ rabbits/treatment) in a completely randomized design. Results obtained indicated that dry matter, crude protein, ether extract, nitrogen free extract, hemicellulose, acid and neutral detergent fibre intake and digestibility decreased with increasing level of sugarcane rind inclusion. Crude fibre intake $(5.59-8.67 \mathrm{~g} /$ day) and digestibility $(20.60-40.80 \%)$ however increased $(P<0.05)$ as level of sugarcane rind increased in the diet. The $30 \%$ inclusion of sugarcane rind gave body weight gain $(5.35 \mathrm{~g} / \mathrm{d})$ comparable to the control $(6.41 \mathrm{~g} / \mathrm{d}), 10(7.78 \mathrm{~g} / \mathrm{d})$ and $20 \%(7.12 \mathrm{~g} / \mathrm{d})$ inclusion of sugarcane peels. Feed intake (44.61-40.59 $\mathrm{g} / \mathrm{d}$ ) decreased as the level of sugarcane rind increased in the diets. There was no significant $(P>0.05)$ effect of sugarcane rind on metabolic body weight and feed efficiency. Inclusion of sugarcane rind at $30 \%$ level increased $(P<0.05)$ thigh and head percentage but without any adverse effect on chest, loin, shoulder and skin. Based on the results, it is concluded that sugarcane rind is a good fibre source that can be used to replace maize offal up to $30 \%$ in rabbit diets.

Keywords: Nutrient intake, digestibility, sugarcane rind and rabbit

\section{Introduction}

Rabbit production has gained considerable interest recently in Nigeria because. of the exorbitant prices of conventional sources of beef, chevon, mutton, pork and poultry (Adeyemi and Akanji, 2012). Rabbit meat is high quality meat that is often considered a delicacy. It is high in protein and low in fat, cholesterol, sodium and calories (Damron, 2006). Rabbit meat contains all essential amino acids, minerals and all required vitamins except vitamin $C$ needed by humans (Partridge et al., 1989).

Chewing of sugar cane is a way of life especially in northern Nigeria. The sugarcane is derinded and cut into small sections for chewing. This has resulted in accumulation of sugarcane rinds in towns and villages causing a nuisance by clogging water ways and drains and thus polluting the environment (Saleh, 2008). Sugar cane rind is very available and can be used as a feed resource especially as a source of crude fibre.

Today, in the Nigerian feed industry, maize offal has been found to be widely and successfully used as a good source of crude fibre in the diets of so many species of livestock, rabbits inclusive. This, however, has made its price to skyrocket in the 
market. Hence, there is need to develop more alternative feed resources that can yield same output at cheaper cost when compared to the use of maize offal. One possible way out of this problem is the use of sugarcane rind as possible replacement for maize or wheat offal. In the work of Garba and Abubakar (2016), the authors replaced wheat offal with sugarcane peels meal in Kano Brown goat diets up to $75 \%$ and observed no significant difference in weight gain and feed conversion. Maize offal $(12.07 \% \mathrm{CF})$ and sugarcane rind $(12.7 \% \mathrm{CF})$ have similar crude fibre content as sugar cane rind (Exieshi et al., 2011; Adeosun and lyeghe-Erakpotobor, 2012) and can therefore be used as fibre source in rabbit diets. Rabbits utilize fibrous feed by courtesy of their feeding and digestive strategies (Leng, 2006) based on this, they can utilize the fibre in sugarcane rind. This study was therefore conducted to evaluate the effect of replacing maize offal with sugarcane peels as a source of crude fibre on nutrient intake, digestibility, growth and carcass characteristics of rabbits.

\section{Materials and Methods}

\section{Location of Experiment}

The study was conducted at the University Farm, Faculty of Agriculture, Bayero University, Kano. The farm is located at the New Site of the University, about $5 \mathrm{~km}$ West of Kano City in Ungogo Local Government Area. Kano is located within the general area demarcated by the lines of longitude $8^{\circ} \mathrm{E}$ and $9^{\circ} \mathrm{E}$ and latitude $12^{\circ} \mathrm{N}$ and $13^{\circ} \mathrm{N}$ in the Northern Guinea Savannah Zone of Nigeria. The area has two seasons, a wet season (May-September) and dry season (October-April). Annual temperature ranges between 21 and $39^{\circ} \mathrm{C}$. In the wet season, the temperature range is $25-33^{\circ} \mathrm{C}$, while in the dry season the range is $28-39^{\circ} \mathrm{C}$. Annual rainfall ranges between 787 and 960mm (KNARDA, 2001).

\section{Animals and their management}

Twenty five growing rabbits of mixed breeds with average initial weight of $894 \pm 26.14 \mathrm{~g}$ were used for the experiment. The rabbits were treated with an antibiotic to clear any pending infections, anti-stress and deworming medications were also provided, for the first five days of the study. The experimental diets were gradually used to replace the feed the animals were used to in the first week as an adjustment period.

\section{Diets Formulation and Feeding Procedure}

Sugarcane rinds were collected from sugarcane selling points within the metropolitan areas of Kano State. The rinds were sun dried on a cemented floor for 4 days and finally milled with a hammer mill to produce sugarcane rind meal. Five experimental diets were formulated to contain varying levels of sugarcane rind to replace maize offal at $0,10,20,30$, and $40 \%$ inclusion levels (Table 1).

One hundred and fifty grams of experimental diet was served to each animal per day in earthen feeders. Feed intake was recorded by subtracting the left over from the amount of feed offered the animals. Growth performance, expressed by weight gain was recorded by weighing the rabbits weekly. Data collection for feed intake and weight changes was carried out for seven weeks.

\section{Digestibility Study}

This study was carried out on the seventh week of the feeding trial. Feed intake and faecal output from each animal was recorded daily at 9:00am for seven days. At the end of faecal collection period, the samples were bulked for each animal for proximate analysis according to $\mathrm{AOAC}$ (1990) and thoroughly mixed and representative samples of the experimental diets, faecal samples and sugarcane rind 
Table 1: Experimental Diets fed to rabbits

\begin{tabular}{lccccc}
\hline & \multicolumn{5}{c}{ Sugarcane peel level (SCP \%) } \\
Ingredient & $\mathbf{0}$ & $\mathbf{1 0}$ & $\mathbf{2 0}$ & $\mathbf{3 0}$ & $\mathbf{4 0}$ \\
\hline Maize offal & 40 & 30 & 20 & 10 & 0 \\
Sugarcane peels & 0 & 10 & 20 & 30 & 40 \\
Maize & 25 & 25 & 25 & 25 & 25 \\
Soya bean meal & 15 & 15 & 15 & 15 & 15 \\
Groundnut cake & 15 & 15 & 15 & 15 & 15 \\
Bone meal & 3 & 3 & 3 & 3 & 3 \\
Palm oil & 1 & 1 & 1 & 1 & 1 \\
Premix & 0.5 & 0.5 & 0.5 & 0.5 & 0.5 \\
Salt & 0.5 & 0.5 & 0.5 & 0.5 & 0.5 \\
Total & 100 & 100 & 100 & 100 & 100 \\
Nutrient Composition: & & & & & \\
CF (\%) & 8.96 & 10.51 & 12.31 & 13.95 & 15.57 \\
CP (\%) & 16.41 & 15.48 & 15.51 & 14.96 & 14.65 \\
Energy (Kcal ME/kg) & 2426 & 2361 & 2338 & 2304 & 2262 \\
Feed cost (A/kg) & 51.19 & 42.96 & 35.32 & 28.25 & 21.91 \\
\hline
\end{tabular}

were analysed for proximate composition as outlined by AOAC (1990) and Van Soest et al. (1991). Dry matter was determined by drying the samples at $105^{\circ} \mathrm{C}$ for $24 \mathrm{~h}$ using a Memmert convection oven. Total nitrogen content was determined by the macrokjeldahl method. The nitrogen content was converted to crude protein by multiplying by the factor 6.25 . Crude fibre was determined as the fraction remaining after digestion with standard solution of sulphuric acid and sodium hydroxide under controlled conditions. Ash was determined by ashing at $550^{\circ} \mathrm{C}$. Ether extract was determined using Soxhlet extraction procedure. For the energy content determination, an adiabatic bomb calorimeter was used.

\section{Carcass evaluation}

Carcass evaluation was conducted at the end of the experiment. Two rabbits were randomly selected from each treatment for carcass analysis. The rabbits were fasted for twenty four hours to clear the gut before slaughter. The rabbits were stunned, bled, skinned and eviscerated. Carcass weight was taken and recorded before and after skinning. The dressed carcass were weighed and expressed as percentage of the live weight to obtain dressing percentage. Weights of the cut parts such as hind legs, fore legs, thigh (femur, fibula, tibia and calcaneus), shoulder (scapula, ulna and radius), loin, chest, head were obtained and expressed as a percentage of carcass weight.

\section{Statistical Analysis}

The values obtained for nutrients intake, digestibility, daily weight gain, feed efficiency, feed intake, metabolic body weight and meat parts were subjected to analysis of variance in a Completely Randomized Design using the General Linear Model Procedure and pair-wise difference was used to separate significant means (SAS, 1987).

\section{Results and Discussion Nutrient Intake}

Dry matter and crude protein intake decreased with increasing level of crude fibre in the diet (Table 2). This agrees with the work of Adegbola and Okonkwo (2002), who reported decreased dry matter intake from 66.85 to $44.24 \%$ and crude protein intake of 11.32 to $7.51 \%$ for rabbits fed a 


\section{Adeosun and lyeghe-Erakpotobor}

level of sugarcane peel increased in the diets. This is in line with the report of Bawa et al. (2008b) who reported decreased crude protein digestibility as the level of maize cob increased in the diet fed to rabbits. Crude protein digestibility obtained in this study are higher than that reported by Bawa et al. (2008a) who obtained a range of 76.28 - $81.18 \%$, for rabbits fed with varying levels of groundnut haulms and cowpea shells, but is in agreement with the range of $60.45-93.54 \%$ reported by Taiwo et al. (2005) who fed rabbits with forages supplemented with concentrate.

Ether extract digestibility obtained in this study were comparable with the range of 88.10 - $93.92 \%$ reported by Bawa et al. (2008a), while ash digestibility were higher than that reported by the same authors, but fell within the range of $85.29-96.84$ observed by Taiwo et al. (2005). Nitrogen free extract digestibility obtained was within the ranges of $69-82 \%$ and $73.70-$ $89.01 \%$ reported by Iyeghe-Erakpotobor et al. (2006b) and Bawa et al. (2008a) respectively.

Digestibility of crude fibre increased with increasing level of sugarcane rind in the diet, this could be attributed to lower feed intake recorded with increasing level of sugarcane rind in the diet, this agrees with the findings of Martinez et al. (2007) who reported increase in crude fibre digestibility with decrease in feed intake for rabbits fed a diet in which lucerne hay was substituted by mulberry leaves. Nworgu et al. (2001) also reported increase in crude fibre digestibility with increasing level of crude fibre in the diets of rabbits when a mixture of leaf meals and concentrates were fed to growing rabbits. Crude fibre digestibility obtained in this study is within the range of $24.96-44.43 \%$ reported by Adegbola and Okonkwo (2002), but lower than $43-55 \%$ and 85.86 - $97.24 \%$ observed by Iyeghe-Erakpotobor et al. (2006b) and Taiwo et al. (2005).

The digestibility values obtained for crude fibre in this study are lower than those of the other nutrients. This may be due to the fact that rabbits are less efficient at digesting fibre than ruminants as reported by Joyce et al. (1971). Likewise, Cheeke el al. (1986) stated that dietary fibre has a low digestibility in rabbits, because the digestive strategy of the rabbit is to separate the larger fibre particles from smaller nonfibre substances in the hindgut thereby excreting the fibre in the faeces. The lower values recorded in crude fibre digestibility were in line with the observation of Nworguet al. (2001).

Table 3: Nutrient Digestibility of Growing Rabbits fed graded level of Sugarcane Peel

\begin{tabular}{|c|c|c|c|c|c|c|c|}
\hline \multirow[b]{2}{*}{ Nutrient (\%) } & \multicolumn{5}{|c|}{ Sugarcane Peel Level $(\%)$} & \multirow[b]{2}{*}{ SEM } & \multirow[b]{2}{*}{ Prob. } \\
\hline & 0 & 10 & 20 & 30 & 40 & & \\
\hline Dry Matter & $78.37^{a}$ & $78.32^{\mathrm{a}}$ & $76.24^{b}$ & $73.75^{c}$ & $72.52^{c}$ & 2.08 & $<0.0001$ \\
\hline Crude Protein & $92.63^{\mathrm{ab}}$ & $93.21^{a}$ & $91.83^{\mathrm{bc}}$ & $92.49^{: b b}$ & $90.77^{\circ}$ & 1.54 & 0.0023 \\
\hline Crude Fibre & $20.60^{c}$ & $32.11^{\mathrm{d}}$ & $34.54^{c}$ & $39.51^{b}$ & $40.80^{\mathrm{a}}$ & 1.81 & $<0.0001$ \\
\hline Ether Extract & $90.23^{\mathrm{a}}$ & $90.97^{a}$ & $89.85^{a}$ & $88.31^{b}$ & $87.95^{\mathrm{b}}$ & 1.63 & 0.0002 \\
\hline Ash & $92.92^{\mathrm{a}}$ & $92.18^{\mathrm{ab}}$ & $91.17^{\mathrm{b}}$ & $87.74^{c}$ & $87.73^{c}$ & 1.59 & $<0.0001$ \\
\hline NFE & $77.47^{\mathrm{a}}$ & $76.46^{\mathrm{a}}$ & $74.86^{\mathrm{b}}$ & $73.15^{\mathrm{c}}$ & $72.73^{\mathrm{c}}$ & 2.04 & $<0.0001$ \\
\hline
\end{tabular}


cassava leaf meal diet with increase in crude fibre content. The decrease in feed intake as the percentage of sugarcane peel inclusion increased above $20 \%$ SCP in this study is linked to increase in the level of fibre in the diet, and this agrees with the findings of Amata and Bratte (2008) who observed decrease in daily feed intake with increase in crude fibre content from 10.48 to $14.25 \%$ in rabbits fed Gliricidia leaf meal. Also, Jegede et al. (2008) reported decrease in daily protein intake with increasing crude fibre in malted sorghum sprout diets for growing rabbits.

Crude fibre intake (Table 2) increased as the level of sugarcane peels increased in the diets, indicating that crude fibre intake was lower in the control, and higher in $40 \% \mathrm{SCP}$.
This agrees with increased intake with increasing level of crude fibre in the diet observed by lyeghe-Erakpotobor and Esievo (2010) who fed a mixture of soybean cheese waste meal and lablab hay to rabbits. The report of Maigandi and Ngang (2002) was similar to these when rabbits were fed calabash seed cake diet with increasing level of crude fibre. Ether extract, ash and nitrogen free extract intake decreased with increase in level of sugarcane peel. This supports the work of lyeghe-Erakpotobor et al. ( 2006a) who observed decrease in nutrients intake with increase in crude fibre level when varying levels of soybean cheese waste/mâize offal diet and Brachiaria grass hay were fed to weaner rabbits.

Table 2: Nutrient Intake of Growing Rabbits fed graded levels of Sugarcane Peel

\begin{tabular}{|c|c|c|c|c|c|c|c|}
\hline \multirow[b]{2}{*}{ Nutrient (g/d) } & \multicolumn{6}{|c|}{ Sugarcane Peel Level ( $\%)$} & \multirow[b]{2}{*}{ Prob. } \\
\hline & 0 & 10 & 20 & 30 & 40 & SEM & \\
\hline Dry Matter & $59.99^{: 1}$ & $62.15^{\mathrm{a}}$ & $59.51^{\mathrm{a}}$ & $54.01^{\mathrm{b}}$ & $54.30^{\mathrm{b}}$ & 6.24 & 0.0007 \\
\hline Crude Protein & $10.24^{a}$ & $10.05^{\mathrm{ab}}$ & $9.45^{\mathrm{b}}$ & $8.41^{\circ}$ & $8.16^{\circ}$ & 1.01 & $<0.0001$ \\
\hline Crude Fibre & $5.59^{\mathrm{d}}$ & $6.85^{\circ}$ & $7.50^{\mathrm{b}}$ & $7.84^{b}$ & $8.67^{a}$ & 1.05 & $<0.0001$ \\
\hline Ether Extract & $8.98^{a}$ & $9.30^{a}$ & $7.86^{b}$ & $6.85^{\circ}$ & $6.14^{d}$ & 0.85 & $<0.0001$ \\
\hline Ash & $6.92^{b}$ & $7.62^{i}$ & $6.9 \mathrm{I}^{\mathrm{b}}$ & $6.86^{b}$ & $6.81^{b}$ & 0.76 & 0.0101 \\
\hline NFE & $30.69^{a}$ & $31.13^{\mathrm{a}}$ & $29.22^{i}$ & $26.23^{b}$ & $25.74^{\mathrm{b}}$ & 3.16 & $<0.0001$ \\
\hline
\end{tabular}

abc Means in the same row with different superscripts are significantly different. SEM= Standard error of mean. Prob. $=$ probability.

\section{Nutrient Digestibility of Rabbits}

Digestibility of dry matter, crude protein, ether extract, ash, and nitrogen free extract decreased with increasing level of sugarcane peels inclusion (Table 3 ) in the diets. This agrees with the findings of Adegbola and Okonkwo (2002) who fed cassava leaf meal to rabbits and reported decreased nutrient digestibility as crude fibre increased in the diet. Doma et al. (1999) and Gidenne (1996) also observed that as fibre level in rabbit diets increased, the dry matter and other nutrient digestibility decreased. The level at which crude fibre determines increase or decrease in digestibility of a feed is a function of the type of fibre that is present in the feed (Doma et al., 1999). They discovered significant decrease in dry matter and crude protein intake with increasing dietary fibre level of maize cob diets, and significant increase in dry matter and crude protein intake with increasing dietary fibre level of cowpea shell diets fed to rabbits. Dry matter digestibility values obtained in this study fall within the range of $67-81 \%$ and 61.16 $87.03 \%$ reported by Adegbola and Okonkwo (2002) and Bawa et al. (2008a) who fed cassava leaf meal and varying levels of groundnut haulms and cowpea shells to rabbits respectively.

Crude protein digestibility decreased as the 


\section{Growth Performance}

The inclusion of sugarcane rind at $40 \%$ dietary level significantly reduced weight gain when compared to rabbits on $10 \% \mathrm{SCR}$ (Table 4). The decrease in daily weight gain with increase in crude fibre level is in support of the findings of Nworgu et al. (2001) and Babatunde et al. (1999) who fed a mixture of leaf meals and concentrates, and graded levels of Pueraria phaseoloide leaf meal to rabbits respectively. Weight gain by the rabbits followed a trend closely similar to that of feed intake, suggesting that the reduction in feed intake played an important role in the reduction in weight gain. Feed efficiency, though numerically increasing with increase in sugarcane peel level was not significantly $(\mathrm{P}<0.05)$ affected by dietary treatments and this agrees with the no significant difference in the feed efficiency of rabbits fed Gliricidia leaf meal by Amata and Bratte (2008).

Table 4: Growth and Carcass Characteristics of Rabbits fed graded level of Sugarcane Peels

\begin{tabular}{|c|c|c|c|c|c|c|c|}
\hline \multirow[b]{2}{*}{ Parameter } & \multicolumn{5}{|c|}{ Sugarcane Peel Level (\%) } & \multirow[b]{2}{*}{ SEM } & \multirow[b]{2}{*}{ Prob. } \\
\hline & 0 & 10 & 20 & 30 & 40 & & \\
\hline Metabolic Body Weight (kg) & 1.15 & 1.21 & 1.20 & 1.11 & 1.06 & 0.11 & 0.25 \\
\hline Average Daily Gain (g/day) & $6.41^{\mathrm{ab}}$ & $7.78^{\mathrm{a}}$ & $7.12^{\mathrm{ab}}$ & $5.35^{\mathrm{ab}}$ & $4.70^{\mathrm{b}}$ & 1.57 & 0.05 \\
\hline Feed Efficiency & 7.44 & 6.23 & 7.41 & 9.02 & 9.33 & 5.75 & 0.39 \\
\hline Meat Parts ( $\%$ Carcass weight) & & & & & & & \\
\hline Thigh & $19.91^{\mathrm{b}}$ & $20.14^{b}$ & $20.53^{b}$ & $21.83^{\mathrm{a}}$ & $20.43^{b}$ & 0.38 & 0.05 \\
\hline Chest & 12.70 & 12.81 & 11.65 & 12.85 & 11.30 & 0.79 & 0.44 \\
\hline Head & $9.63^{b}$ & $9.17^{\mathrm{b}}$ & $9.66^{\mathrm{b}}$ & $10.71^{\mathrm{a}}$ & $9.27^{b}$ & 0.29 & 0.04 \\
\hline Loin & 8.34 & 8.72 & 8.53 & 9.10 & 8.19 & 0.94 & 0.94 \\
\hline Shoulder & 8.04 & 7.57 & 8.56 & 8.80 & 8.14 & 0.51 & 0.18 \\
\hline Skin & 11.20 & 9.38 & 10.61 & 10.67 & 9.48 & 0.73 & 0.12 \\
\hline Hind Legs & 1.61 & 1.45 & 1.54 & 1.67 & 1.51 & 0.08 & 0.08 \\
\hline Fore Legs & 0.67 & 0.61 & 0.65 & 0.69 & 0.61 & 0.04 & 0.55 \\
\hline
\end{tabular}

${ }^{\mathrm{ab}} \mathrm{Means}$ in the same row with different superscripts are significantly different. SEM= Standard error of mean. Prob. $=$ probability.

\section{Carcass Characteristics}

Thigh and head proportions increased significantly as sugarcane rind meal level increased in the diet up to $30 \%$ SCR. However, chest, loin, shoulder, skin, fore and hind legs were not affected by sugarcane rind meal level. This probably shows that the inclusion of sugarcane rind in the diet of growing rabbits had positive influence on these parts. Bawa et al. (2008a) fed varying levels of groundnut haulms and cowpea shells to weaner rabbits and reported no significant difference in head and thigh, but significant improvement in dressing percentage, intestine, skin, loin with increase in crude fibre content of the diets. This is at variance with results obtained in this study. These differences could be attributed to the nature of the fibre source, age differences of the rabbits and length of the adaptation period of their digestive system to the fibre source, as reported by Alawa and Amadi (1991).

\section{Conclusion}

Based on the results of this study, it can be concluded that:

The decrease in daily weight gain and feed intake could be accountable for by the decrease in dry matter and crude protein intake and digestibility as sugarcane rind increased in the diet.

Crude fibre intake and digestibility increased as sugarcane peels increased in the diet, meaning that sugarcane peels is a good fibre source that can replace maize 
offal in rabbit diet.

Inclusion of $30 \%$ SCR significantly improved thigh and head weight, while the inclusion did not adversely affect daily weight gain or other meat parts. This shows that the addition of sugarcane peels up to this level is of benefit for rabbit production.

\section{References}

Adegbola, T.A. and Okonkwo, J. C. 2002. Nutrient Intake, Digestibility and Growth rate of Rabbits fed varying levels of cassava leaf meal. Nigerian Journal of Animal Production. 29(1):21-26.

Adeosun, T. A. and Iyeghe-Erakpotobor, G. T. 2012. Performance of Growing Rabbits fed Graded Levels of Sugarcane Peel Diets. Nigerian Journal of Animal Science, 14:81-91.

Adeyemi, O. A. and Akanji, A. O. 2012. Effect of Concentrate Feed Restriction with ad libitum Forage Feeding on Performance and Carcass Yield of Growing Rabbits. Nigerian Journal of Animal Science, 14:101-112.

Alawa, J. P. and Amadi, I. C. 1991. Voluntary feed intake and digestibility of diets containing corn cobs, brewers dried grains and wheat bran by rabbits. J. Anim. Prod. Res. 11:9-20.

Amata, I. A. and Bratte, L. 2008. The effect of partial replacement of soybean meal with gliricidia leaf meal on the performance and organ weights of weaner rabbits in the tropics. Asian Journal of Animal and Veterinary Advances. 3(3): 169-173.

AOAC 1990. Association of Official Analytical Chemists. Official Method of Analysis (15ed.) Vol. 1
Arlington, Virginia, USA

Babatunde, A., Kolade, J. J. and Ogunlade, J. T. 1999. Performance and carcass quality of weaner rabbits on graded levels of puerariaphaseoloide leaf meal in the diet. Tropical Animal Production Investigations. 2(2): 187-193.

Bawa, G. S., Ajide, S. O., Adeyinka, I. A. and Ajala, M. K. 2008a. Effects of varying l e v e l s of groundnut haulms and cowpea shells on performance of weaner rabbits. Asian Journal of Animal and Veterinary Advances 3(2):5461

Bawa, G. S., Ogundipe, S. O., Sani, O. P., Akpa, G. N. and Jokthan, G. E. $2008 \mathrm{~b}$. Effects of varying levels of maize cobs supplemented with Allzyme or Maxigrain on performance of young rabbits. Proceedings of the $13^{\text {th }}$ Annual Conference of the Animal Science Association of Nigeria (ASAN), 2008.Pp: 392-395.

Cheeke, P. R., Grobner, M. A. and Patton, N. M. 1986. Fibre Digestion and Utilization in Rabbits. Journal of Applied Rabbit Research, 9(1): 25-30.

Damron, W. S. 2006. Introduction to Animal Science. Global, Biological, Social and Industry Perspectives. (3rd edition), 816pp.

Doma, U. D., Adegbola, T. A., Bamgbose, A. M. and Umeh, P. A. 1999. Utilization of cowpea shell and maize cobs in diets for rabbits. Tropical Journal of Animal Science. 2(1): 27-32.

Exieshi, E. V., Obazele, O. M. and Olomu. J. M. 2011. Performance and Energy Metabolism by Broiler 
Chickens fed Maize and Millet Offals at different Dietary Levels. Journal of Agriculture and Social Research, 2(1). http//dx.doi.org $/ 10.43$ 14\%2fjasr.vii/i. Retrieved on $26 / 01 / 2014$.

Gidenne, T. 1996. Nutrition and Ontogenic Factors affecting Rabbit Caecocolic Digestive Physiology. In: Lebas, F. (ed) Proceedings of the $6^{\text {th }}$ World Rabbit Congress Association Francaise de Cuniculture, Lempdes, pp. 13-28.

lyeghe-Erakpotobor, G. T., Aliyu, R. and Uguru, J. 2006b. Evaluation of concentrate, grass and legume combinations on performance and nutrient digestibility of grower rabbits under tropical conditions. African Journal of Biotechnology. 4(20):2004-2008.

lyeghe-Erakpotobor, G. T. and Esievo, L. O. 2010. Performance of growing rabbits fed soybean cheese waste meal diet and lablab hay. Nig. J. Anim.Prod.37(2):173-183.

Iyeghe-Erakpotobor, G. T., Osuhor, C. U. and Olugemi, T. S. 2006a. Performance and digestibility of weaner rabbits fed graded levels of soybean cheese waste/maize offal diet and brachiaria grass hay. African Journal of Biotechnology. 5(17): 1579-1583.

Jegede, A. V., Fafiolu, A. O., Falaye, O. J. and Oduguwa, O. O. 2008. Utilization of

Diets Containing malted Sorghum Sprout (msp) by Growing Rabbits. An International Journal of Agricultural Sciences, Sciences, Environment and Technology. 8(2). (www.unaab.edu.ng/journal/index. php/index). Retrieved on $02 / 11 / 11$.

Joyce, P. J., Battray, P. V. and Parker, J.
1971. Utilization of Pasture and barley by Rabbits in Food Intake and Live Weight gains. New Zealand Journal of Agricultural Research. 14:173-179.

Kano Agricultural and Rural Development Authority (KNARDA) 2001. Metrological Station Reports, Temperature Record Book and Management Unit. No. 3-11.

Leng, R. A. 2006. Digestion in the rabbit -a new look at the effects of their feeding and

digestive strategies. Workshop-seminar "Forages for Pigs and Rabbits" MEKARN-CelAgrid, Phnom Penh, Cambodia, 22-24 August, 2006. Article\#18.http://www.me karn .org/proprf/leng.htm.

Maigandi, S. A. and Ngang, F. I. 2002. Performance of Rabbits fed varying levels

of Calabash Seed Cake. Journal of Agriculture and Environment. 3(2):201-208.

Martinez, M., Motta, W. Cervera, C. and Pla, M. 2007. Feeding mulberry leaves to fattening rabbits: effects on growth, carcass characteristics a

n d meatquality.(http://journals.cambri d g e org/a b s t r a c t S1357729805000329). Retrieved on $01 / 11 / 11$.

Nguyen, T. K. D. and Nguyen, T. G. 2008. Effects of Different Levels of Neutral

Detergent Fibre in the diets on Feed Utilization, Growth Rate and Nutrient Digestibility of growing Crossbred Rabbits. MEKARN Workshop 2008: Organic Rabbit Production from Forages. http://www.mekarn.org/prorab/do 
ngcit.htm. Retrieved on 10-11-11.

Nworgu, F. C., Egbunike, G. N. and Osayomi, O. J. 2001. Performance of growing

rabbits fed a mixture of leaf meals and concentrates. Tropical Animal Production Investigations.4(1): 37-48.

Partridge, G. G., Garthwaite, P. H. and Findlay, M. 1989. Protein and energy retention by growing rabbits offered diets with increasing proportions of fibre. $J$. Agric. Sci. 112:171.

Ramchurn, R., Dullull, Z. B., Ruggoo, A. and Raggoo, J. 2000. Effects of f e e d ing star grass (Cynodonplectostachyus) on growth and digestibility of nutrients in the domestic rabbit. Livestock Research for Rural Development 12 (2): 2000. (http://www.cipav.org.co/Irrd12/2/ ram122.htm). Retrieved on $12 / 11 / 2011$.

Saleh, G. 2008. Utilization of Sugarcane Peels in the Diet of Growing Yankasa Lambs.M.Sc. Dissertation, Department of Animal Science, Bayero University, Kano.
Saleh, G. and Abubakar, A. 2016. Performance and nutrients intake of fattening Kano Brown buck goats fed diets containing sugarcane peels meal. Int. Journal of Innovative Agriculture and Biology Research. 4(4): 1-6.

Statistical Analysis System (SAS) 1987. SAS/STAT. Guide for Personal Computers, Version 6, pp. 697 978. SAS Institute, Cary, NC.

Taiwo, A. A., Adejuyigbe, A. D., Adebowale, E. A., Oshotan, J. S. and David, O. O. 2005. Performance and nutrient digestibility of weaned rabbits fed forages supplemented with concentrate. Nig. J. Anim. Prod. 32(1):74-78.

Van Soest, P. J., Robertson, J. B. and Lewis, B. A. 1991. Symposium: Carbohydrate Methodology, Metabolism and Nutritional Implications in Dairy Cattle: Methods for Dietary Fibre, and Non-Starch Polysaccharides-in Relation to Animal Nutrition. J. Dairy Sci. 74: 3585-3597.

Received: $5^{\text {th }}$ August, 2016 Accepted: $4^{\text {th }}$ February, 2017 